\title{
Contemporary Arabic Songs and their Urgency in Learning Arabic Phonetics in the Industrial Revolution \\ 4.0
}

\author{
Zubaidah $^{1}$, Yulia Rahman ${ }^{2}$ \\ \{zubaidah@iainbukittinggi.ac.id ${ }^{1}$, yuliarahman100787@gmail.com² ${ }^{2}$, \\ Faculty of Tarbiyah and Teacher Training, Institut Agama Islam Negeri (IAIN) \\ Bukittinggi, Indonesia ${ }^{1,2}$
}

\begin{abstract}
Arabic is aninternational language approved by the United Nations (UN). The younger generation should be enthusiastic to learn Arabic, not only for religious reasons but also because Arabic is a large, beautiful language, and is one of the oldest languages in the world. As a language, Arabic is very beautiful and interesting. Besides, Arabic is also very easy to pronounce. It can be proven with the high numbers of the fans of Arabic songs in the present time and the appearance of the famous and popular singers who sing in Arabic. Singers like Humood al Khuder with Kun anta, Maher Zain with In sya Allah, Barakallah, Ramadan, Idhak, and many other songs, also NissaSabiyan who is not an Arab but is famous for her Arabic songs that are hits and are well approved by the community in all ages who enjoyand love to recite the song even though they do not understand the translation of the song. This condition is considered as the first step in learning Arabic; that Arabic is easy and that learning Arabic it is not a difficult thing to do. Learning any language should start from the easiest step because language is a habitual knowledge, not something that can be measured based on someone's IQ. If someone finds a language is interesting then one will find out that learning this particular language is easy and will not becomea burden.This article presented a way to learn Arabic by making used of the contemporary Arabic songs.
\end{abstract}

Keywords. Contemporary Arabic Songs, Arabic Learning, Industrial revolution 4.0

\section{Introduction}

The industrial revolution 4.0 is a new term for the present according to the latest conditions and the latest technological developments. The term "Industrie 4.0" comes from a project in the German government's advanced technology strategy that prioritizes computerization of factories. The term "Industrie 4.0" was reappointed at the Hannover Fair in 2011. In October 2012, the Working Group on Industry 4.0 presented recommendations on the implementation of Industry 4.0 to the German federal government. Members of Industry 4.0 working groups are recognized as founding fathers and pioneers of Industry 4.0. The final report of Working Group Industry 4.0 was presented at the Hannover Fair on April 8, 2013. This term is also used in various fields to say a recent situation in the field including learning. Very many seminars and workshops in various fields of science support the term industrial 
revolution 4.0, including in the field of education. This is something significant that there is a fundamental change from Era 4.0 where all lines of education must follow the flow of technology and information both in terms of curriculum, methods and even media in learning.[1]

In the context of 21 st century learning, learning that focused on creativity, critical thinking, collaboration, communication skills, community, and character skillsmust be maintained so that the students of an educational institution still need technical skills. The utilization of various learning activities that support the industrial revolution 4.0 is a necessity with resource sharing models with anyone and anywhere, classroom and lab learning augmented with virtual materials, interactive, challenging, and content-rich learning is not just complete. The world of education in the era of the industrial revolution is in the age of knowledge with the acceleration of an extraordinary increase in knowledge. The accelerated increase in knowledge is supported by the application of digital media and technology called information super highway. The style of learning activities in the knowledge age must be adjusted to the needs of the knowledge age. Learning materials must provide a more authentic design for through challenges where students can collaborate to create solutions to solve the problem of learning. Problem solving leads the students to questions and seeking answers themselvesand then they can look for the problem solving in the context of learning by using the available information resources.[2]

Learning Arabic often seems scary and boring. Why do such things happen in this sophisticated era? The reason is because some people think that Arabic is a classic subject that for religious matters only. To read books, to translate, and interpret verses, even though in reality a language is a tool to communicate and to understand one another. Any language is the same and nothing is difficult to learn, because language ability is not intelligence but habituation.[3]

There is a new phenomenon developsin nowadays societye.g. the music industry that affects the other side of human lives.People are enthusiastic about music and songs that emerge and imitate the style and even the appearance of the singers they like. Music and songs are often heard everywhere: in traditional and modern markets, in the city buses or in public transportation, street buskers, houses, national televisions, and various other places. Children, youngster, adults, and even elderly listen to music. The most interesting thing is the ability of the people to recite and imitate religious songs including Arabic songs that they do not understand the meaning of, e.g. ones popularized by the SabiyanGambus group who are not native Arabs in addition to the popular songs from native Arabs such as Maher Zein, and Humood al Khuderwho are also familiar and commonly recited by the public.

One of the general principles of learning is that learning should be conducted by considering the individual characteristics of students regarding emotional development, intellectual development, social conditions, and cultural environment. Based on these general principles, learning Arabic today should pay attention to the characteristics of today's students as mentioned above. In other words, Arabic learning today should be interesting and fun, as outlined in government regulation No. 19 of 2005 chapter IV article 19 paragraph 1 which states: "The learning process in the education unit is carried out interactively, aspiratively, fun, challenging, motivating students to participate actively, as well as providing sufficient space for initiative, creativity, and independence according to talent, interests, and physical development, as well as psychological learners." Learning as regulated by the government is often referred to as the PAIKEM GEMBROT (Pembelajaranaktif, inovatif, kreatif, efektif, menyenangkan, gembira, danberbobot- active, innovative, creative, effective, fun, happy, and weighty 
learning)learning model. For today's learning, the supplementary learning model is called BERJAS (berbasisjejaringsosial) which means social networking based.[1]

Now, learning Arabic is no longer a scary or boring thing.By looking at the phenomenon that exists today, learning Arabic can be fun and interesting since many people like Arabic songs and they are reducing the burden and fear in learning Arabic. This situation will also attract students at the middle or upper level education in learning Arabic just like ones they do in other foreign languages learning through songs and films in Korean, Thai, Japanese, and English.[4]

Songs are a fantastic way to help students work on different elements of language learning. There are many different ways to use songs in the classroom, from sing-a-longs to more structured listening exercises, depending on the class you have and the goals you have in mind. A more structured exercise will take a bit longer to prepare, but it will be far more helpful for the students. Ideas for structured exercises will depend on the grammar points you are trying to teach, but they can include fill-in-the-blank exercises, writing exercises to continue the song or even creating adaptations of the song with new words. [5]

Students today tend to get pleased with songs, especially the songs that suit their tastes. Therefore, the teachers should be able to utilize their passion for the songs as one of the learning techniques e.g. by singing while learning Arabic. The utilization of the songs in this study aims to (1) foster students' sensitivity to sound, rhythm, and tone in Arabic; (2) practice the pronunciation and use of vocabulary in songs; and (3) practice the use of phrases or sentence patterns in songs. In learning Arabic through songs, educators should pay attention to the principles of song selection which include (1) the song should not be too long, (2) the language used in the song is not too difficult, (3) the theme of the song should be according to the characteristics of the students, (4) the song contains Arabic material to be trained, and (5) the song should contain wisdom or moral / character education. Educators can carry out the following procedures in teaching Arabic through songs: educators (1) inform the title of the song, (2) sing a song or play a recorded song to attract the attention of students, (3) display a song poem which is also an Arabic learning material, (4) explain the meaning of vocabulary in the song, (5) explain the sentence patterns that exist in the song, (6) practice the application of vocabulary in the sentence, (7) practice making sentences based on the sentence patterns in the song, (8) with students singing the song in groups, or individually.[6]

Learning a language with singing can be easy and fun by following the steps:[5]

- Listen to the song

- Ask some questions about the title

- Listen to the song again, this time with lyrics

- Focus on a particular verb tense or aspect of grammar

- Focus on vocabulary, idioms and expressions

- Round things off with some creativity[7]

The steps above can be applied in learning Arabic, using contemporary Arabic songs and fusha (fluent). In this paper, particularly, for learning phonetics or sound which is also understood by learning MkharijulHuruf. Teachers do not only have to focus on repeating the letters one by one, but can use the songs to teach the correct phonetics.[8] 


\section{Contemporary Arab Song As A Media In Teaching Arabic Phonetics}

Phonetics in Arabic is the study of the sound of letters or in Arabic it is called al-Ashwat, the letters are called hijaiya letters whose learning tends to be classic, there are not many writings that contain phonetic learning, learning methods or media. Previous studies of this discussion include the following:

- Song as a medium for learning Arabic grammar (Nahwu) written by Nanang Joko Purwanto in Maharat Journal, Arabic Language Study Program at Muhammadiyah University, Yogyakarta. This paper discusses songs as learning media for Arabic Grammar.[9]

- Music (song) media in Arabic learning at MI level. written by Hasan in a journal article with the ISBN Arabic Language Banjarmasin. Which discusses the media of songs for learning Arabic for children.[10]

- Learning Arabic through songs, written by Taufiqurrahman in applied science research, State University of Malang. This paper discusses songs for learning Arabic for children (ALA) Al ArabiyahlilAthfal.

\subsection{Ashwat learning at the primary level}

In this case students do not have the knowledge of the language.The learning of Arabic sound (ashwatarabiyah) that needs to be done is as follows:[11]

1. Using the alphabet method (الأبجدية)

In this method, introducing the names of letters and autographs (forms of writing) is the beginning of teaching literacy. Furthermore, the sound of consonants (dead letters) is introduced after being combined with vowels to form a phoneme, for example [b-u bu-d-i di]. Because Arabic letters are all consonants, in Arabic words vocal marks are created which are placed above and below the letters. So at the stage of sound recognition presented letters marked with vocals, for example as follows:

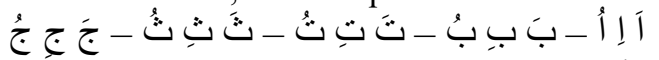

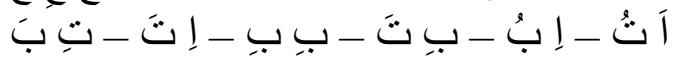

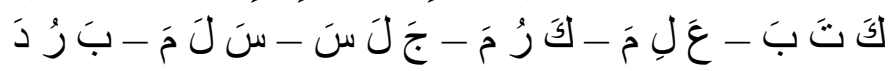

2. Sound method (الصوتية)

In this method learning begins directly in sound. In this case there are two commonly used methods, namely the way of synthesis (stringing) and the analytical method (peeling).

3. Synthesis Method (الصوتية التركييية)

This method begins by introducing the sound of letters, then strung together into words, example:

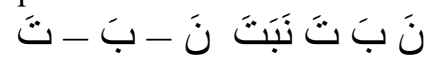

4. Analysis method (الصوتية التحليلية)

Starting with the word then peeled into the sounds of letters. Or starting with a sentence, then peeled into words, and peeled again into letters. Example:

$$
\text { }
$$

This method of analysis usually starts with the introduction of words that are familiar to students or for foreign languages with the help of pictures.

5. Analysis-synthesis method (التحليلية التركيبية)

This method is a combination of the two methods. The examples are as follows: 


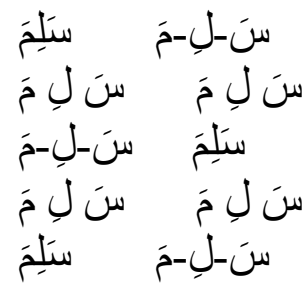

The first of the global and then peeled into parts and then back to global again. The second of the parts is then combined into one unit, and then returns to the parts again.

\subsection{Ashwat learning at the secondary level}

The method of synthesis and analysis is a method carried out at this intermediate level. In this intermediate level students should already have some vocabulary or mufrodat, and therefore learning arobiyyahashwat must be integrated with students' knowledge of mufrodat For example by using:

1. Synthesis method (الصوتية التركيبية)

This method begins by introducing letters and then strung together into words. As an example:

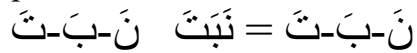

2. Analysis method (الصوتية التحليلية)

This method begins with words then peeled into letter sounds or starts with sentences, then peeled into words, and peeled again into letters. Example:

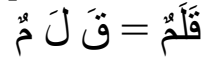

Both of these techniques integrate ashwat and mufrodat, so students can add mufrodat and also pronounce them properly and correctly, thus creating fluency and fluency in daily experience.In this level, studentsalready have some knowledge about Arabic, so in learning arabiyahashwat more integrated in mufrodat. For example with listening exercises, an example of a teacher reciting:

$$
\begin{aligned}
& \text { و اللهُ سَمِيعُ بَصِيرٌ }
\end{aligned}
$$

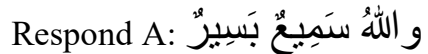

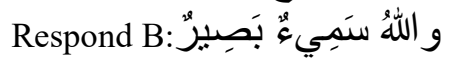

Or by listening or imitating exercises, although listening exercises aim to practice hearing, but in practice they are always followed by pronunciation and comprehension exercises. In the initial stage, students are trained to listen and imitate. This activity is carried out by the teacher, when introducing new words or sentence patterns, or in a time deliberately devoted to listening exercises. This mimicking exercise, focused on Arabic sounds that are foreign to students, also on long and short vowel sounds, tasydid and no-tasydid, are unknown in Indonesian.

\subsection{Ashwat learning at an advanced level}

At this level, all beginner and intermediate level learning can be combined and continued using contemporary Arabic songs, the instructor can analyze in advance what letters are difficult to pronounce, because Arabic has several letters which are close to the sound and 
where the letters come out, but the properties are different. Usually difficult letters are found in adjacent letters that sound like:
1.
2. $\vec{b}-\vec{c}$
3.

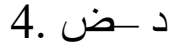

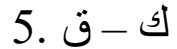
6. ح- هـ
7. $\square-j-j$
8. $\dot{\varepsilon}-\dot{\tau}$

The letters above are letters that are usually difficult to teach because they have adjacent sounds and adjacent makhraj, the difference is the nature of the letters. Usually the conventional method teaches to pronounce these letters over and over again even to form a mouth so that the letters pronounced vary, even it is not uncommon for the teacher to put his hand down to press the position of the letter and its exit. Like other languages, Arabic should be easier and more fun, because calling the letters is not different from the symbol of the letter, like English the letter A is read "Ei" and B is read "Bi", while Arabic distinguishes the letters that are read bold and thin, it's just that for some people it becomes difficult.

Among the famous contemporary Arabic songs is kun anta from Humood al Khuder, where this song is very booming at all, almost all circles can sing it, along with dominant letters that are difficult and close to sound can be learned easily and pleasantly.

Song I

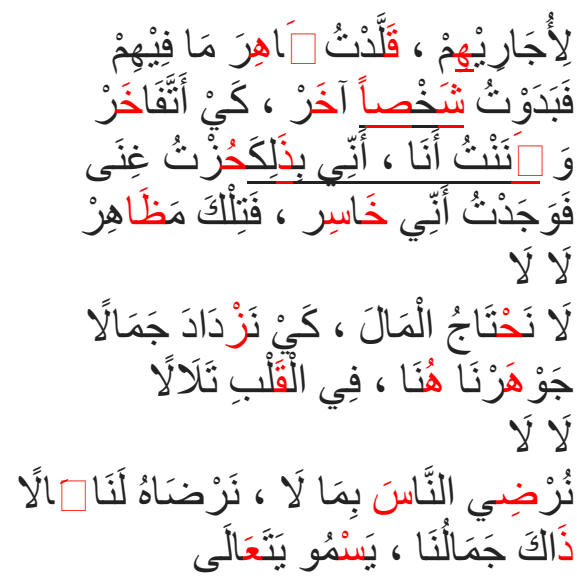

The letters in red are identified as letters that are on average difficult to pronounce, while those given a line are contained in a single line of letters that have a sound that is close together but differs in makhraj and nature. To teach letters that are adjacent to the sound, it is recommended to repeat the song by looking at the lyrics and memorizing them whenever possible. After that the teacher can simply correct the letters by repeating the words in the song.

Song II

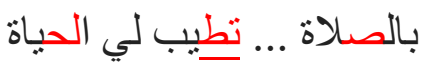




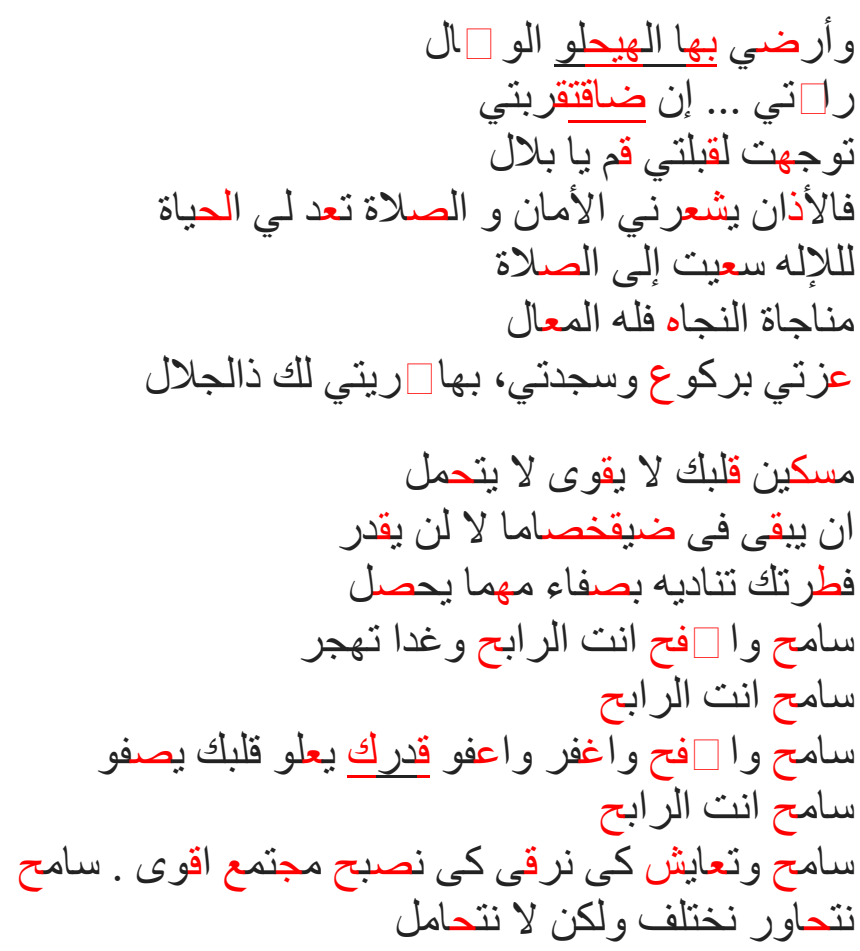

The song above is also effective for teaching Arabic phonetics, which is very clearly seen in the verses of the letters identified that are difficult to pronounce, by teaching them through songs, the difficulty of pronouncing will be easily overcome and learning even fun. Another thing that teachers need to consider in choosing Arabic songs is the selection of songs that are Fusha, Fusha or fluent is where the words used are not the dialect of a region and all Arab nations understand it as well as people from different parts of the world. To make the most of phonetic learning by using contemporary Arabic songs, there are several steps in learning:

- Choose the song that is most familiar to students

- $\quad$ Look at the song lyrics and then follow together

- Exemplify the correct reading and sound of letters that correspond to letters that are considered difficult and mark the letters.

- Repeat words and follow students

- Repeat overall and listen to each student's pronunciation.

- After all students recite in accordance with the phonetic letters, the instructor conducts a random test of the letters of the letters.

The following are some of the contemporary Arabic songs that can be used as a medium for learning the Arabic phonetic, and the authors have tried out some students with good responses and have no difficulty and are boring in learning letters or phonetics:

\begin{tabular}{|c|c|c|}
\hline Song Title & Singer & Description \\
\hline لغات , هاأناذا , كن فضوليا , اضحك / Edhak & $\begin{array}{l}\text { Humood al } \\
\text { Khuder }\end{array}$ & $\begin{array}{l}\text { Humood Comes from Kuwait } \\
\text { Most of the Humood songs are in Arabic Fusha }\end{array}$ \\
\hline
\end{tabular}




\begin{tabular}{|c|c|c|}
\hline $\begin{array}{c}\text { Song Title } \\
\end{array}$ & Singer & $\begin{array}{l}\text { Description } \\
\end{array}$ \\
\hline عبد سعيد , روطي فداك ,تبسم/Tabassam & $\begin{array}{l}\text { Messut } \\
\text { Kurteis }\end{array}$ & A native of the Republic of Macedonia \\
\hline Halmil Han/ لم الحان & Aseel Omran & $\begin{array}{l}\text { This Arabic singer is famous in Indonesia } \\
\text { because the song won the star cast by Via } \\
\text { Valen }\end{array}$ \\
\hline 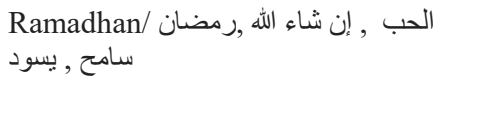 & Maher Zein & $\begin{array}{l}\text { Originally from Sweden } \\
\text { Most Maher Zein songsare in Arabic and there } \\
\text { are mixed with English and others }\end{array}$ \\
\hline $\begin{array}{l}\text { Ya jamalu, Lau Kana Bainanal Habib } \\
\text {, Ya Habibal Qolbi, Ya Maulana, } \\
\text { Rohman ya Rohman }\end{array}$ & $\begin{array}{l}\text { Nissa } \\
\text { Sabiyan }\end{array}$ & Indonesian singer whose songs are in Arabic \\
\hline Atouna el Toufuli & Nancy Ajram & Lebanese singer \\
\hline
\end{tabular}

\section{Conclusion}

There are many ways or innovations that can be done in general language learning specifically Arabic, so that Arabic does not become a feared language, such as using songs as a learning medium, in addition to being used for learning grammar and teaching children songs can be used for ashwat learning ( phonetic) for various groups. In accordance with the times, songs including Arabic songs are also developing, this can be seen with the emergence of new singers who sing Arabic songs. Not only the singer, the public was enthusiastic about the songs and could even memorize and recite them. This is seen as a progress and great benefits for learning Arabic, especially phonetics. Contemporary Arabic songs that have sprung up lately are so popular with the public that they can be used to teach phonetics. Teaching phonetics with Arabic songs will be easy, interesting and not boring.

\section{References}

[1] Muhaiban, "Pembelajaran Bahasa Arab Zaman Now," 2005, pp. 1-16.

[2] S. Zubaidah, "Keterampilan Abad 21: Keterampilan yang diajarkan Melaui Pembelajaran," 2016.

[3] U. R. Baroroh, Lagu Sebagai Model Pembelajaran Bahasa Arab untuk Anak dan Pemula. Yogyakarta, 2011.

[4] Muhaiban, "SEMINAR KONASBARA5,” in بنام النعبلم الإلكتروني على أساس الموقع الشبكي لتعليم اللغة العربية

[5] T. English, "2 018 New Ideas for Teaching English Using Songs and Music," 2001.

[6] A. J. Simpson, "How to use songs in the English language classroom | British Council," British Council. 2015.

[7] "9 Hip Modern Songs for Teaching English to All Levels.".

[8] A. K. Khitam, "Phonological Dimension of the Arabic Word: The INtimate Rnlation Betwin Sound and Meaning in the Arabic Words," Arab. J., vol. 4 No. 1.

[9] N. J. Purwanto, "No Media Lagu Untuk Pembelajaran Bahasa Arab (Nahwu)," Mahara Univ Muhammadiyah Yogyakarta, vol. I, pp. 1-13, 2019.

[10] Hasan Syahrin, "Media Musik (Lagu) dalam Pembelajaran Bahasa Arab MI,” 2016.

[11] S. Akbar, "Strategi Pembelajaran Ashwat al Arabiyah dan Strategi Pembelajaran Mufradat," 2015. [Online]. Available: https://bacaakbar.wordpress.com/2015/09/06/strategi-pembelajaran-bahasaarab-strategi-pembelajaran-ashwat-arabiyah-strategi-pembelajaran-mufradat/. 